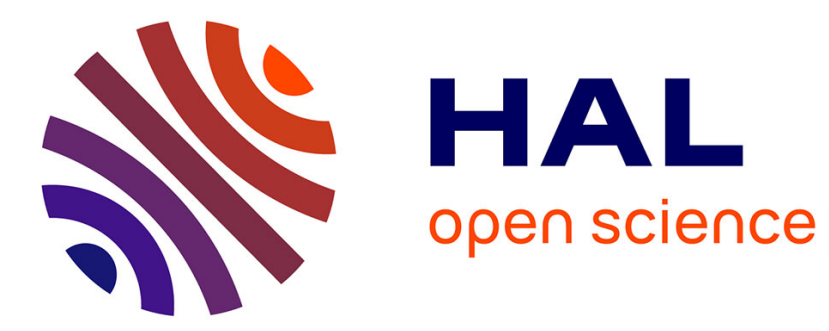

\title{
Optimizing Design of Household Scale Hybrid Solar Photovoltaic + Combined Heat and Power Systems for Ontario
}

P Derewonko, Joshua M Pearce

\section{- To cite this version:}

P Derewonko, Joshua M Pearce. Optimizing Design of Household Scale Hybrid Solar Photovoltaic + Combined Heat and Power Systems for Ontario. 34th IEEE Photovoltaic Specialists Conference (PVSC), Jun 2009, Philadelphia, United States. 10.1109/PVSC.2009.5411247 . hal-02120506

\section{HAL Id: hal-02120506 https://hal.science/hal-02120506}

Submitted on 6 May 2019

HAL is a multi-disciplinary open access archive for the deposit and dissemination of scientific research documents, whether they are published or not. The documents may come from teaching and research institutions in France or abroad, or from public or private research centers.
L'archive ouverte pluridisciplinaire HAL, est destinée au dépôt et à la diffusion de documents scientifiques de niveau recherche, publiés ou non, émanant des établissements d'enseignement et de recherche français ou étrangers, des laboratoires publics ou privés. 


\title{
OPTIMIZING DESIGN OF HOUSEHOLD SCALE HYBRID SOLAR PHOTOVOLTAIC + COMBINED HEAT AND POWER SYSTEMS FOR ONTARIO
}

\author{
P. Derewonko and J. M. Pearce * \\ Department of Mechanical and Materials Engineering \\ Queen's University, 60 Union Street,Kingston, ON K7L 3N6 Canada \\ * Corresponding author: pearce@me.queensu.ca phone 613-533-3369 fax 613-533-6610
}

\begin{abstract}
This paper investigates the feasibility of implementing a hybrid solar photovoltaic (PV) + combined heat and power (CHP) and battery bank system for a residential application to generate reliable base load power to the grid in Ontario. Deploying PV on a large-scale has a penetration level threshold due to the inherent power supply intermittency associated with the solar resource. By creating a hybrid $\mathrm{PV}+\mathrm{CHP}$ system there is potential of increasing the PV penetration level. One year of one second resolution pyranometer data is analyzed for Kingston Ontario to determine the total amount of PV energy generation potential, the rate of change of $\mathrm{PV}$ power generation due to intermittent cloud cover, and the daily CHP run time required to supply reliable base load power to the grid using this hybrid system. This analysis found that the vast majority of solar energy fluctuations are small in magnitude and the worst case energy fluctuation can be accommodated by relatively inexpensive and simple storage with conventional lead-acid batteries. For systems where the PV power rating is identical to the CHP unit, the CHP unit must run for more than twenty hours a day for the system to meet the base load requirement during the winter months. This provides a fortunate supply of heat, which can be used for the needed home heating. This paper provides analysis for a preliminary base line system.
\end{abstract}

\section{INTRODUCTION}

Historically, solar photovoltaic (PV) deployment in Ontario has been limited, contributing a negligible percentage of the energy mix. This historical trend was due primarily to the relatively high costs of PV. This trend is poised to reverse as the Ontario Power Authority has proposed one of the most aggressive feed in tariffs (FIT) in the world [1]. The Ontario FIT is slated to provide home owners with roof-mounted PV systems $<10 \mathrm{~kW}$ with an CAD $\$ 0.802 / \mathrm{kW}$-hr grid feed in rate on 20 year contracts. Thus, the quantity of PV installed in Ontario is expected to increase substantially in the next several years. With or without the FIT, the learning curve for $\mathrm{PV}$ and economies of scale are driving prices of PV towards grid parity [2-5]. When the cost of PV electricity is equivalent to conventional grid electricity, the PV penetration level is set only by technical limitations. The primary technical limitation of the penetration level of PV, or percentage of PV in the energy supply, is the natural variation in power generation caused by the diurnal cycle, the yearly cycle, and intermittent cloud cover [6]. The inherent power supply intermittency makes PV alone unable to fully replace a new power plant operated in base load. Ontario has more than $31,000 \mathrm{MW}$ of electricity generating capacity, but because of aging nuclear reactors, Ontario's commitment to phasing out coal-fired power plants and a steadily increasing demand for electricity, there will likely be a 30,000 MW gap between available and required capacity by 2025 [7]. Increasing the PV contribution from negligible levels today to high penetration levels in Ontario has many well documented benefits including: i) decreased pollution and greenhouse gas (GHG) emissions [8], ii) relieved transmission congestion problems, and iii) improved grid reliability by reducing summer black-out occurrences [9]. However, at higher penetration levels of PV generation while using conventional technologies, corrective measures such as assigning more generating units to regulating duty or installing fast-response combined-cycle generators must be incorporated into the grid to compensate for the intermittency of PV generation. These new generators may be partially loaded, which decreases the overall grid efficiency due to the increased fuel consumption and maintenance costs associated with partially loaded generators [10].

The development of small scale (on the order of a kW) combined heat and power (CHP) systems has provided the opportunity for in-house power backup of residentialscale PV arrays and thus a potential solution to this challenge. Recent work investigates the potential of deploying a distributed network of such $\mathrm{PV}+\mathrm{CHP}$ hybrid systems in order increase the PV penetration level in the U.S. [11]. In order to explore this solution for Ontario, this study begins the investigation of the feasibility of implementing a hybrid solar photovoltaic + combined heat and power (CHP) + battery bank system to supply the grid with base load power. This system has the potential of increasing PV penetration levels without introducing partially loaded generators, thus avoiding typical drawbacks associated with high penetrations of PV. This paper reports on an investigation of the temporal distribution of solar flux using second-resolved data over one year from both a pyranometer and building-integrated solar photovoltaic array in Kingston, Ontario. This paper will quantify the frequency of large changes in PV generation ( $\mathrm{dE} / \mathrm{dt}$ ) caused by intermittent cloud cover in Ontario. This information will be used to determine the boundary conditions set on both the CHP and battery response times necessary to operate at base load. In addition, the total amount of available energy lost due to cloud cover is calculated and the amount of CHP overlap needed per month to provide the grid with reliable base load PV energy is determined for Kingston ON. The method presented here is generalizable for any location 
with reliable solar flux data.

\section{BACKGROUND}

Although higher penetration levels of PV generation can be problematic without appropriate safeguards, basic corrective measures such as assigning more generating units to regulating duty have been available for over twenty five years [12]. A relatively small penetration level of $5 \%$ or less enables the system's utility to track the changes and has been viewed as the upper limit for PV [13]. Currently, with $<1 \%$, PV does not approach this upper limit, however, because the utility reluctance to embrace large-scale distributed generation with intermittent sources such as PV is in part due to the fact that at high penetration levels the savings offered by intermittent generations could be offset by the increase in utility costs to maintain partial loads of reserves, making it uneconomical to add intermittent generations into utility systems. As an increasing number of conventional generating units are recruited to back up PV and partially loaded to add load-following capability and operating reserve to the system with high percentage of $P V$, the overall grid efficiency can drop because of increased cycling duties and decreased efficiency caused by the partial loading of these generators, which will increase fuel consumption and maintenance costs.

The variations in the PV power that create this problem is due to i) diurnal cycle, ii) yearly cycle, and iii) fluctuating cloud conditions. Variations i) and ii) have been addressed in ref. 6 with the $\mathrm{PV}+\mathrm{CHP}$ system as a whole. The more challenging problem, iii) of fluctuating cloud conditions and thus rapidly changing PV power, will be addressed here, but on first approximation can be partially solved simply by deploying solar PV systems over a larger geographic area. For example, if a network of PV installations is dispersed throughout a large area such as $100 \mathrm{~km}^{2}$, the acceptable penetration level of PV increases to $18.1 \%$, and if the area again expands to 1,000 $\mathrm{km}^{2}$, the limit is set at $35.8 \%$ [14]. In a review of several studies, an estimate of the upper penetration limit of PV generation is set at about $16 \%$ of the system load set by the worst-case cloud pattern [15]. It should be noted that in these studies, the penetration level is the real time percentage not the overall percentage of PV electricity generation, which would of course be considerably less as peak sun hours are only available for a few hours each day. Here we will look at a more realistic scenario (with intermittent cloud cover), where these penetration level numbers will be significantly reduced without some means of storage such as battery backup. This paper will use better time resolved PV outputs throughout the day and year to provide a more refined design using the available CHP technologies and their response times for Ontario in order to increase the PV penetration level.

\section{METHODOLOGY}

\section{Data Collection and Analysis}

All data for this project was collected from the Queen's University Live Building PV array, shown in Fig. 1, which consists of 264 polycrystalline silicon solar panels capable of generating $20 \mathrm{~kW}$. This array is located on the side of Goodwin Hall in Kingston, Ontario Canada (44 ${ }^{\circ} 13^{\prime} \mathrm{N}$ latitude and $76^{\circ} 29^{\prime} \mathrm{W}$ longitude). The array is tilted at $70^{\circ}$ from the horizontal to optimize the passive solar aspect of the design. This tilt angle also eliminates the complication of snow shadowing, which can have a significant impact on yearly system performance in Canada. According to Schriever, the optimum angle to prevent any snow buildup (zero snow load) is $70^{\circ}$ as the snow load on glass is zero at $70^{\circ}[16]$. This tilt angle also biases energy production to the winter months of the year. The global radiation, to determine solar availability, was measured by a Vantage Pro solar sensor, tilted in the same plane as the PV array. This data can be accessed using PI Processbook and Datalink. The annual solar irradiation data from 2007 was used for the analysis as it was the most complete and had the least number of system shutdown days.

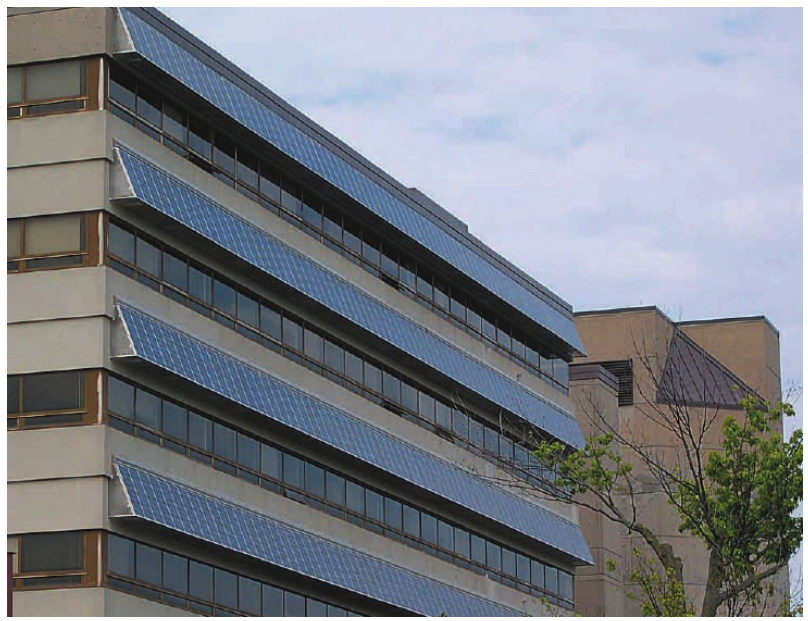

Fig. 1 Queen's University's first $20 \mathrm{~kW}$ solar PV array (photo: Anton Driesse)

All the available one second solar energy data recorded for the PV array and pyranometer over a year was analyzed to determine change in energy available per second as a function of time step, time of day, and time of year. A Matlab program was created to extract the maximum measured irradiance $\left(\mathrm{W} / \mathrm{m}^{2}\right)$, the total amount of measured energy (E) and histogram data for the change in PV generation (dE/dt). The solar energy lost due to cloud cover was determined by subtracting the measured solar energy from the available solar energy on an ideal cloudless day. To find ideal cloudless solar data, it was assumed that the variation in daily available solar energy throughout a single month was negligible. Then, the monthly data sets were viewed graphically to find a day in each month with a nearly ideal solar energy distribution (least amount of power fluctuations) and a high peak solar irradiance. A second Matlab program was created to omit the minor power fluctuations from the data set. The program determined hourly maximum solar irradiance values and when they took place, and stored the data in an array. The available solar energy on an ideal cloudless 
day in the specified month could then be found by fitting a curve through these points and calculating the area under the curve. As an example, a graph of the measured solar irradiance (blue) and the curve created by the second program (red) for a nearly cloudless day in February is shown in Fig. 2. This methodology is ineffective if there are long periods of overcast cloud cover.

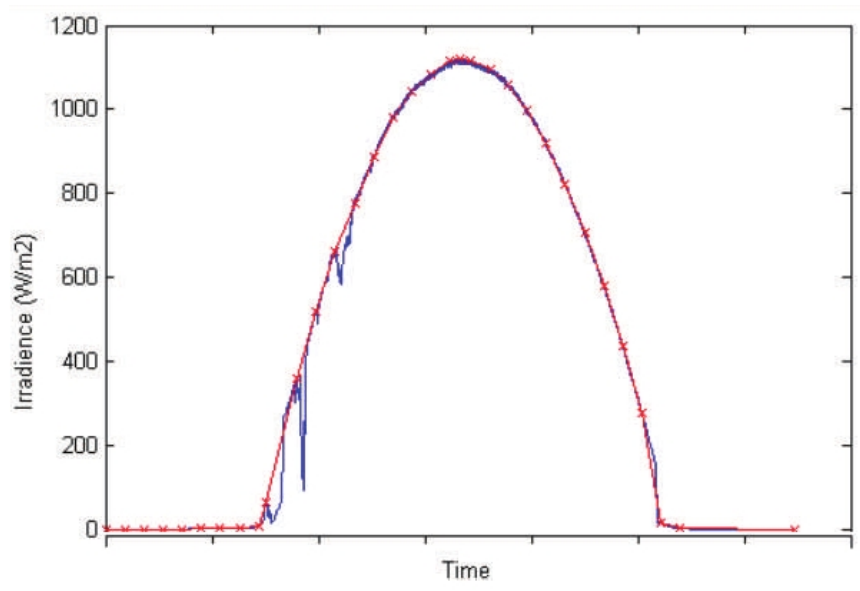

Fig. 2. Results of a program to plot the solar irradiance $\left(\mathrm{W} / \mathrm{m}^{2}\right)$ while omitting minor power fluctuations due to intermittent cloud cover.

\section{Hybrid PV+CHP+Battery Bank Residential System Design}

The basic hybrid system is designed for residential homes to generate a base load amount of electricity to the grid without the negative effects associated with the fluctuating nature of PV electricity. This can be accomplished by designing the hybrid system with a standard $1.2 \mathrm{~kW}$ PV array, a $1.2 \mathrm{~kW}$ CHP unit and a battery bank. Specifications for the three suitable micro-CHP technologies are summarized in Table 1.

Table 1. Micro-CHP specifications [17,18,19]

\begin{tabular}{|c|c|c|c|}
\hline Manufacturer & WhisperGen & Freewatt & Ballard \\
\hline Technology & Stirling Engine & Honda MCHP & $\begin{array}{c}\text { PEM Fuel } \\
\text { Cell }\end{array}$ \\
\hline Type & $\begin{array}{c}4 \text { cylinder } \\
\text { double-acting } \\
\text { Stirling cycle }\end{array}$ & $\begin{array}{l}\text { 4-stroke single } \\
\text { cylinder engine }\end{array}$ & $\begin{array}{c}1030 \mathrm{~V} 3 \\
\text { home fuel cell }\end{array}$ \\
\hline $\begin{array}{r}\text { Electrical } \\
\text { Output }\end{array}$ & $\begin{array}{c}1000 \mathrm{~W} @ 230 \mathrm{~V} \\
\mathrm{AC}\end{array}$ & $\begin{array}{c}1200 \mathrm{~W} @ 240 \mathrm{~V} \\
\mathrm{AC}\end{array}$ & $\begin{array}{c}1.234 \mathrm{~kW} \\
\mathrm{DC}\end{array}$ \\
\hline $\begin{array}{r}\text { Thermal } \\
\text { Output }\end{array}$ & 7.5-12 kW & $3.5 \mathrm{~kW}$ & $\mathrm{~N} / \mathrm{A}$ \\
\hline Fuel & Natural gas & $\begin{array}{c}\text { Natural gas or } \\
\text { Propane }\end{array}$ & Hydrogen \\
\hline Ramp Rate & $5 \mathrm{~min}$ & $5 \mathrm{~min}$ & $\begin{array}{c}20 \text { sec. } \\
\text { (1020ACS } \\
\text { model) }\end{array}$ \\
\hline
\end{tabular}

The Freewatt model was chosen for this system analysis because the WhisperGen model is currently only available to UK residents, and the Ballard fuel cell model adds complexities regarding hydrogen storage and lowcycling performance. Using the Freewatt CHP unit, the system will sized to produce $1.2 \mathrm{~kW}$ of base load power to the grid. During hours of high solar flux, the instantaneous $\mathrm{PV}$ energy is the primary energy source, and the CHP unit is turned off. However, the CHP unit runs continuously during the non-solar hours of the day and during an additional specified overlap time with the low irradiance hours of the day (morning and evening), generating a base load of $1.2 \mathrm{~kW}$ using natural gas as a fuel. The heat generated from the process is used to heat the home, or to run an absorption chiller to provide cooling in the summer. The PV electricity generated during the CHP overlap hours is used to charge a battery bank. The instantaneous PV energy is not capable of generating a base load of $1.2 \mathrm{~kW}$ alone due to its natural fluctuating power output. The battery bank therefore supplies the additional power needed to provide the grid with reliable base load electricity while the CHP unit is off.

The system methodology is shown in Fig. 3, where the power is given as a function of time of day for an example highly variable solar flux day in January. The PV generation is shown in blue, the CHP output in red, and the excess power provided by the system is shown in green. As can be seen in Fig. 3, in this example the CHP unit is run all night and turned off at 10AM and then turned back on at 2PM. The PV energy used to charge the battery bank during the low irradiance hours of the day (area under the green curve and above $1200 \mathrm{~W}$ ) should approximately equal the make-up energy needed during the high irradiance hours of the day (area above blue curve and below $1200 \mathrm{~W}$ ). This enables the amount of energy provided by the PV array to be maximized. The specified amount of CHP overlap with PV generation must vary throughout the year because the amount of solar energy available also varies throughout the year.

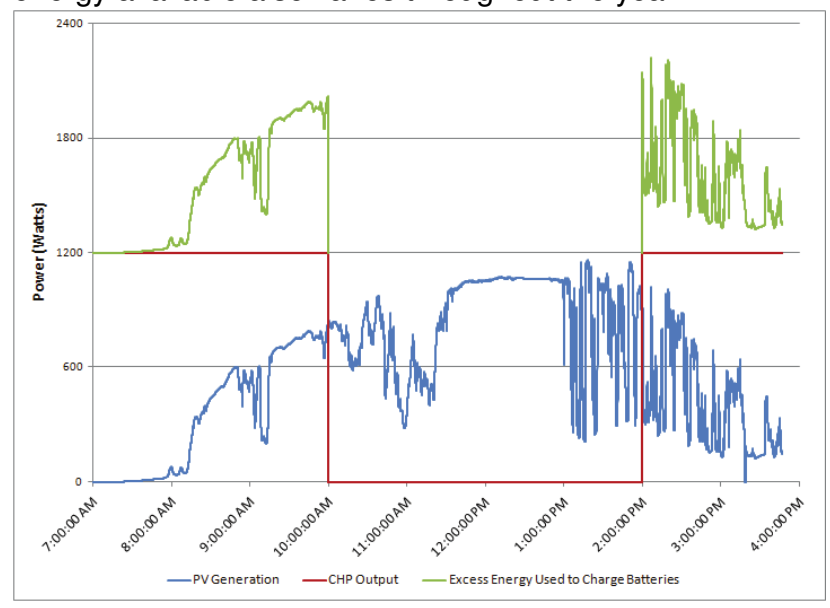

Fig. 3. Power of the $\mathrm{PV}+\mathrm{CHP}+$ Battery system is given as a function of time of day for an example with a highly variable solar flux. It should be noted that an optimized system will provide a steady $1200 \mathrm{~W}$ of power. 


\section{RESULTS AND DISCUSSION}

Following the methodology described above the monthly and annual results were calculated for the PV energy generated, the average cloud loss per day, and the total cloud loss are summarized in Table 2.

Table 2: Summary of analyzed 2007 Kingston monthly PV energy, average cloud loss per day and total cloud loss for the month.

\begin{tabular}{|l|ccc|}
\hline & $\begin{array}{c}\text { Monthly } \\
\text { Photovoltaic } \\
\text { Energy } \\
(\mathrm{kWh})\end{array}$ & $\begin{array}{c}\text { Average } \\
\text { Cloud Loss } \\
\text { per Day } \\
(\mathrm{kWh})\end{array}$ & $\begin{array}{c}\text { Total } \\
\text { Cloud } \\
\text { Loss } \\
(\mathrm{kWh})\end{array}$ \\
\hline Jan. & 86 & 3.92 & 121.67 \\
Feb. & 106 & 3.40 & 95.27 \\
Mar. & 106 & 3.58 & 103.79 \\
Apr. & 73 & 3.59 & 107.81 \\
May & 113 & 1.78 & 55.14 \\
Jun. & 106 & 1.26 & 37.83 \\
Jul. & 97 & 1.56 & 48.37 \\
Aug. & 114 & 1.91 & 59.06 \\
Sept. & 132 & 1.79 & 53.61 \\
Oct. & 92 & 3.63 & 112.45 \\
Nov. & 72 & 4.02 & 120.58 \\
Dec. & 38 & 5.06 & 157.01 \\
\hline Annual & 1133 & 35.50 & 1072.60 \\
\hline
\end{tabular}

The maximum irradiance peaks is lowest in the summer due to the $70^{\circ}$ angle of the Queen's solar array, which is clearly not optimized for PV-electrical energy generation. For a residential system in Ontario the optimal angle will be determined by both the complexity of the system (e.g. absorption chiller) and by economics and the cost of natural gas. If an absorption chiller is included in the design, the CHP unit could provide heat in the winter and cooling in the summer, and a PV array angle producing the required distribution of energy throughout the year should be used. If an absorption chiller is not included, then the PV array should be angled to bias the energy for the summer to reduce the amount of CHP overlap and the resulting waste heat created by the CHP unit. Further work is necessary to optimize a specific design of this system based largely on the economics and the rates for PV generated electricity and the cost of gas.

It is interesting to note, that the annual amount of energy lost due to cloud cover (1,073 kW-hr) is nearly equivalent $(95 \%)$ to the annual amount of energy generated by the PV array $(1,133 \mathrm{~kW}-\mathrm{hr})$. Thus, roughly $50 \%$ of the available solar energy is not captured by the PV array due to cloud cover. This result indicates that either significant battery back-up or a large overlap of CHP with PV generation will be necessary to provide base load for the system even during the day in this region. It also indicates that thin film PV panels, which have better performance in overcast conditions, may be a more suitable choice for the region [20].

\section{Intermittent Cloud Cover}

The frequency of varying magnitudes of solar energy change on a per second basis (dE/dt) was found by extracting histogram data using Matlab, the results for which are shown in Fig. 4. This information is needed to determine the influence of intermittent cloud cover on PV generation and the preliminary information needed to determine the ramp rates of the other system components. The results shown in Fig. 4 illustrate the rarity of intermittent cloud cover affecting PV energy generation in Kingston. The vast majority of the change in solar energy is small in magnitude and is associated with the natural daily cycle of solar energy and noise in the measurement system. However, it is clear that none of the currently available CHP units are able to provide ramp rates fast enough to compensate for the rapid changes in solar flux shown in Fig. 4. A battery of some size is clearly needed to provide energy during intermittent cloud cover. Fortunately, the magnitude of $\mathrm{dE} / \mathrm{dt}$ resulting from intermittent clouds is small with the highest change being $250 \mathrm{~W} / \mathrm{m}^{2} / \mathrm{s}$, which occurs relatively rarely as seen in Fig. 4. This change in discharge rate can be easily accomodated by standard low-cost lead-acid batteries and verifies that neither high-performance batteries or supercapacitors are not needed in the system. The optimal sizing of such a battery bank is left for future work.

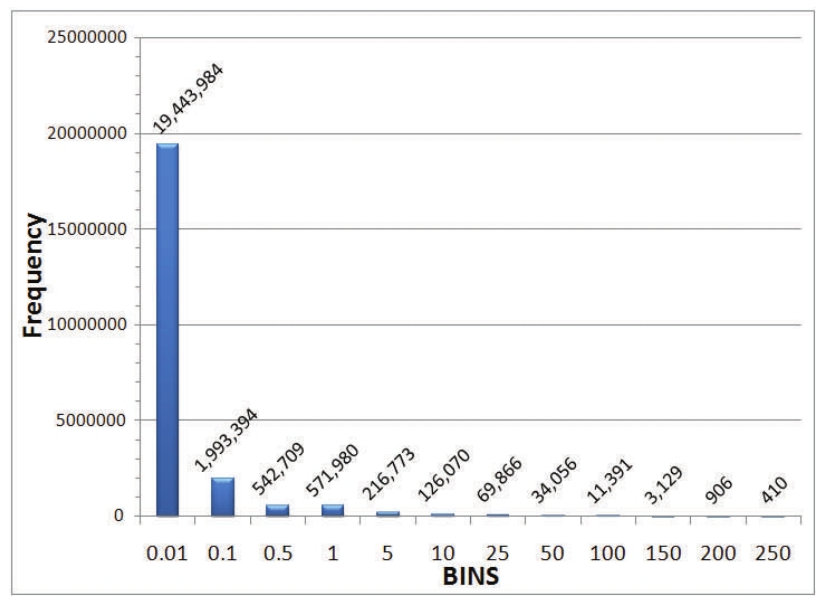

Fig. 4. Histogram for the change in solar energy per second, dE/dt, throughout the year.

\section{CHP Overlap with PV}

The annual amount of energy generated by a $1.2 \mathrm{~kW}$ base load system is 10,512 kW-hrs, which should equal the sum of the energy generated by CHP and PV. This value is also remarkably similar to the average energy use 
for a typical household of 10,654 kW-hrs/year in the U.S. [21]. This indicates that a $1.2 \mathrm{~kW}$ system may be ideally suited for the typical home to be a net zero electricity building. Without the CHP unit, the PV array can generate approximately $11 \%$ of the base load requirement. Using the CHP unit only during non-solar hours of the day, the CHP and PV account for $60 \%$ of the annual energy requirement. Adding an overlap of $\mathrm{CHP}$ with PV generation the system is capable of providing $100 \%$ of the base load energy requirement. The amount of overlap required to provide $100 \%$ of the base load energy is shown in Table 3. Adding the overlap with the amount of non-solar hours represents the daily CHP run time per month.

In order for this system to work effectively to supply base load, the CHP unit must be running for more than 20 hours a day throughout the entire year, which would result in high natural gas use and concomitant operating costs and greenhouse gas emissions. The key factors affecting the overlap time are: the PV array tilt angle, size of the PV array, size of the battery bank, and the base load power requirement. In the winter months, it is beneficial to always have the CHP unit on to heat the home, and therefore, PV energy production is not required. This is fortunate as the solar flux available is minimized in the winter. The PV array can be tilted to bias the PV generation to the warmer months of the year. Also, the CHP overlap can be reduced by using an array larger than that which provides $1.2 \mathrm{~kW}$ of power. Finally, using a CHP unit with a smaller electrical output will reduce the base load power requirement, which increases the percentage of PV energy contribution to the base load and reduces the CHP overlap. It should also be pointed out here to minimize the battery bank size the CHP can also be used in some part to charge the battery bank to cover more of the intermittent radiation cycles. This will decrease the percentage of solar energy but improve the economics of the system if the battery bank is a major cost impediment.

Table 3 Overlap required to provide $100 \%$ base load

\begin{tabular}{|l|cc|}
\hline & $\begin{array}{c}\text { Overlap with } \\
\text { PV Generation } \\
\text { (hours) }\end{array}$ & $\begin{array}{c}\text { Daily CHP run } \\
\text { time } \\
\text { (hours) }\end{array}$ \\
\hline Jan. & 6.75 & 21.75 \\
Feb. & 8.00 & 21.00 \\
Mar. & 9.25 & 21.25 \\
Apr. & 12.00 & 22.00 \\
May & 12.00 & 21.00 \\
Jun. & 12.25 & 21.25 \\
Jul. & 12.50 & 21.50 \\
Aug. & 11.00 & 21.00 \\
Sept. & 8.50 & 20.50 \\
Oct. & 8.75 & 21.75 \\
Nov. & 7.00 & 22.00 \\
Dec. & 8.00 & 23.00 \\
\hline
\end{tabular}

\section{Future Work}

The hybrid PV + CHP + battery bank system presented in this paper must be further optimized to determine the ideal base load power requirement, and the ideal tilt and size of the PV array to minimize the CHP run time and battery bank size. This optimization will not only be highly dependent on local weather conditions and HVAC loads, but also the costs of electricity and CHP fuels. Another concern that was not addressed in this paper is the size of the battery bank, which must be kept to a minimum as it is the system component with the shortest lifespan and replacements may be costly if the size of the battery bank is large.

\section{CONCLUSIONS}

This research begins the investigation of the technical feasibility of implementing a hybrid PV + CHP + battery bank system to supply the grid with base load power. It was found that in the Kingston, Ontario area, $50 \%$ of the available solar energy is lost due to cloud cover. By plotting a histogram of the change in solar energy per second throughout the year, it was found that the vast majority of solar energy fluctuations are small in magnitude and are associated with the natural daily cycle of solar energy. The worst case energy fluctuation can be handled by relatively inexpensive lead-acid batteries.

For the hybrid system to run effectively, the CHP unit must be on for more than twenty hours a day year round, resulting in high natural gas costs and emissions. The system presented in this paper must be optimized by changing key variables such as the base load power requirement, the $\mathrm{PV}$ array tilt angle and the size of the PV array.

\section{ACKNOWLEDGEMENTS}

The authors would like to gratefully acknowledge the technical assistance of A. Driesse and R. Isaza and NSERC Canada for funding support.

\section{REFERENCES}

[1] Ontario Power Authority, "Renewable Energy Feed-In Tariff Program: FIT Rules" Version 1.0, 2009. Available: http://www.powerauthority.on.ca/fit/

[2] L. Neij, "Cost development of future technologies for power generation-a study based on experience curves and complementary bottom-up assessments" Energy Policy 36 (6), 2008, pp. 2200-2211.

[3] M.R. Pinto, "Has the sun finally risen on photovoltaics?," 2008 Symposium on VLSI Technology, , 2008, pp.2-5. 
[4] M.S. Keshner and R. Arya, "Study of potential cost reductions resulting from super-large-scale manufacturing of PV modules", National Renewable Energy Laboratory final subcontract report, 2004, NREL/SR-520-36846.

[5] J. M. Pearce, "Industrial Symbiosis for Very Large Scale Photovoltaic Manufacturing", Renewable Energy 33, 2008, pp. 1101-1108.

[6] J. M. Pearce, "Household-Scale Cogen + Solar Photovoltaic Hybrid Systems: Effects on Penetration and Storage for Eastern Ontario", Conf. Proceedings of the 2009 Solar Buildings Conference, Toronto, 2009.

[7] Ontario Ministry of Energy and Infrastructure, "Why Ontario Needs to Renew Supply", Dec. 2008, Available: http:// www.mei.gov.on.ca.wsd6.korax.net/english/energy/electricity/i ndex.cfm?page=nuclear-electricity-supply.

[8] J. Pearce, "Photovoltaics - A Path to Sustainable Futures", Futures 34(7), 2002, pp. 663-674.

[9] R. Perez, S. Letendre, and C. Herig, "PV and grid reliability: availability of PV power during capacity shortfalls", Proc. ASES Annual Meeting, Forum 2001, Washington, DC.

[10] P. Denholm and R. Margolis, "Very Large-Scale Deployment of Grid-Connected Solar Photovoltaics in the United States: Challenges and Opportunities", U.S. Department of Energy, NREL (National Renewable Energy Laboratory), Conference Proceedings for Solar 2006, Denver 2006, NREL/CP-620-39683.

[11] J. M. Pearce, "Expanding Photovoltaic Penetration with Residential Distributed Generation from Hybrid Solar Photovoltaic + Combined Heat and Power Systems", to be published.

[12] P.M. Anderson, "The Effect of Photovoltaic Power Generation on Utility Operation". Final Report 1984; SAND84-7000. 1984.

[13] S.M. Chalmers, M.M. Hitt, J.T. Underhill, P.M. Anderson, P.L. Vogt, and R. Ingersoll, "The Effect of Photovoltaic Power Generation on Utility Operation". IEEE Transactions on Power Apparatus and Systems 104(3), 1985, pp. 524-530.

[14] W.T. Jewell and T.D. Unruh, "Limits on Cloud-induced Fluctuation in Photovoltaic Generation". IEEE Transactions on Energy Conversion 5(1), 1990, pp. 8-14.

[15] Y. Wan and B.K. Parsons, "Factors Relevant to Utility Integration of Intermittent Renewable Technologies". National Renewable Energy Laboratory, 1993, NREL/TP-463-4953.

[16] W. R.,Schriever, "CBD-193 Estimating Snow Loads on Roofs", Canadian Building Digest, 1978,
[17] Freewatt, "Products", Retrieved March 20 2009, from: http://www.freewatt.com/products.asp (2008).

[18] WhisperGen Heat and Power System, "On-Grid Products", Retrieved March 20 2009, from:

http://www.whispergen.com/main/achomesspecs info/ (2007).

[19] Ballard, "Residential Cogeneration Market", Retrieved March 20 2009, from: http://www.ballard.com/Stationary Power (2008).

[20] R. Gottschalg, C.N.Jardine, R.Ruther, T.R. Betts, G.J.Conibeer, J. Close, D.G. Infield, M.J.Kearney, K.H. Lam, K. Lane, H. Pang, and R.Tscharner, "Performance of amorphous silicon double junction photovoltaic systems in different climatic zones", Conference Record of the $29^{\text {th }}$ IEEE Photovoltaic Specialists Conference, 2002, pp. 1699-1702.

[21] Energy Information Administration (EIA), US Household Electricity Report. Release date: July 14, 2005. Available:

http://www.eia.doe.gov/emeu/reps/enduse/er01 us.html 